that such developments incidentally justify the increased application of technical research in industry. The manifesto concludes with emphasising the need for consolidation in the management field. Asserting that nothing short of a revolution in the general attitude to the operation of industry is needed, it appeals for serious co-ordination of efforts in this field both in the study of management science and in the exposition of its results, so as to raise the standard of management everywhere in industry.

\section{The Case for Alcohol}

IN a monograph entitled "In Chase of Truth of Alcohol", issued by the True Temperance Scientific Committee (Donington House, Norfolk Street, London, W.C.2. 1s.), Prof. H. E. Armstrong gives a vigorous popular exposition, couched largely in parabolic and allusive language, of the origin, relationships and uses of alcohol. In the dedication he states his conviction that in our attitude towards alcohol "we should abolish Pecksniff as our leader and become sensible, like foreign nations". He points out that while vineyards are going out of cultivation and the mash tun is shrinking, the cider-press is advancing in favour: the apple is becoming the rival of John Barleycorn. Taking a broad view of the position, alcohol and opiates (narcotics) have been alternatives throughout history : at the present day "the drunkard no longer disfigures society, but the nuisance of tobacco is everywhere and inescapable". Prof. Armstrong pictures tobacco as a powerful depressant, both of eyesight and of intelligence. Further, while the excessive indulgence in tobacco has induced in this generation a loss of appreciation of good conking, alcohol has the opposite effect.

THE problems of nutrition and alcohol are inseparable, states Prof. Armstrong. The case against the reasonable use of alcohol as a beverage rests largely upon unsound experiments; when taken in moderation at meals, alcohol exerts a favourable effect upon digestion. Constant indulgence in large quantities of dilute alcohol leads to obesity, owing to the effect upon fat metabolism of the lower concentration within the cells, determined by the influx of alcohol. Since the Oriental dietary is near the margin of safety, the artificial ingestion of water induced by the use of alcohol would probably favour downgrade changes and so inhibit the repair of tissues. The proportion of alcohol oxidised in the body is small, but it has a definite metabolic fuel value. As a source of mechanical energy, alcohol is a serious rival to petrol. "To the chemist, alcohol is no mere drug . . . it is a wondrous material, a true elixir of life; the abuse lavished upon it is rarely otherwise than the abuse of ignorance. The fault lies with those who misuse it - these must be set aside, not alcohol."

\section{Early Publication in Anthropology}

Two notes, pregnant with suggestion for the field archæologist engaged in palæolithic research, appear among the communications presented to the Institut français d'Anthropologie last session ( $L$ 'Anthropologie, T. 42, Nos. 5-6, pp. 679-682). As they indicated lines of search in connexion with matters which, it is suggested, may hitherto have escaped the attention of excavators, it was important that their publication, in however brief a form, should have been as speedy as possible. In one note, the Abbé Breuil described a spear-point of bone of Mousterian age from the cave of Castillo (Santander). No object in bone of this type of Mousterian age was previously known, except an example found by Dr. H. Martin at La Quina in 1913. M. Breuil suggested a resemblance to the wooden spear found by Mr. Hazzledine Warren, associated with a Clactonian industry, at Clactonon-Sea, and pointed out that such finds as this indicated that the Mousterians were in fact acquainted with the working and polishing of bone. This note was followed by a second, by Dr. Martin, in which he described the bone point of Mousterian age found at La Quina and also a point, or rather poignard, made from the canon bone of a horse, which had been found in 1905. Before the discovery of this latter, bone work by the Mousterians was not known. $\mathrm{He}$ suggested that the rarity of Mousterian bone work was due to the fact that the deposits, in which Mousterian remains were found, were not favourable to the preservation of objects of bone, or these were not recognised by excavators. In view of the importance of these announcements, it is most unfortunate that although they were presented to the Institut at a meeting held in February last year, the report has only just been published.

\section{International Geological Congress}

THE postponed sixteenth session of the International Geological Congress will be held in Washington this year on July 22-29. A long series of excursions has been organised for the period July 9 August 30, and it has fortunately been possible, through the generous assistance of the Geological Society of America, to offer the longer excursions at a considerable reduction below the actual cost. In selecting participants, where the number is to be limited, preference will be given to geologists whose special interests accord with the major objects of the excursion, and to geologists from foreign countries. Two important changes in the arrangements should be noted. The period covered by the excursions and the general sessions now falls entirely within the summer vacation of British and European universities. The resource topic originally chosen, "Petroleum Resources of the World", has now been dropped in favour of copper resources, and authoritative papers bearing on this subject are invited with the view of the publication of a special volume. Full particulars of the conditions of membership, topies for discussion, and itineraries and costs of excursions are given in the third circular, which can be obtained, together with application forms for membership, from the General Secretary, Sixteenth International Geological Congress, United States Geological Survey, Washington, D.C.

\section{International Congress of Physical Chemistry}

ON the occasion of its twenty-fifth anniversary, the French Society of Physical Chemistry is arranging 